Goldschmidt 2021 Abstract

https://doi.org/10.7185/gold2021.6439

\section{Surface Radioactive Heat Production from in situ Gamma Spectrometry and Chemical Data of Mantle exhumed peridotites from St. Peter and St. Paul Archipelago (Equatorial Atlantic)}

THOMAS FERREIRA DA COSTA CAMPOS ${ }^{1}$, ESTEFAN MONTEIRO FONSECA ${ }^{2}$, JOSÉ HUMBERTO ARAUJO ${ }^{3}$, VALÉRIA F S PASTURA ${ }^{4}$, SUSANNA SICHEL ${ }^{2}$, KENJI MOTOKI $^{2}$, LEONARDO BARÃO ${ }^{5}$, MARCIA MAIA ${ }^{6}$, DANIELE BRUNELLI ${ }^{7}$, JOAQUIM VIRGENS NETO ${ }^{8}$, THAIS VARGAS ${ }^{9}$ AND PETER SZATMARI ${ }^{10}$

${ }^{1}$ Federal University of Rio Grande do Norte Brazil

${ }^{2}$ Universidade Federal Fluminense

${ }^{3}$ Universidade Federal do Rio Grande do Norte

${ }^{4}$ Comissão Nacional de Energia Nuclear (CNEN)

${ }^{5}$ Universidade Federal do Paraná

${ }^{6}$ Université de Bretagne Occidentale

${ }^{7}$ Università degli Studi di Modena e Reggio Emilia

${ }^{8}$ CPRM

${ }^{9}$ Universidade do Estado do Rio de Janeiro

${ }^{10}$ Petrobras

Presenting Author: thomascampos@geologia.ufrn.br

The mapping of radioactive heat production (RHP) and the respective radioactive heat flow (RHF) of Saint Peter and Saint Paul Archipelago (SPSPA), based on radioactive heat-producing elements (RPE) data from whole-rock chemical analysis and in situ Gamma radiation spectrometry. The SPSPA show a radioactive heat production that ranging from 0.08 to 0.68 $\mu \mathrm{W} / \mathrm{m}^{3}$ (Median: $0.21 \mu \mathrm{W} / \mathrm{m}^{3}$ and Geometric mean: $0.25 \mu \mathrm{W} / \mathrm{m}^{3}$ ) by whole-rock chemical analysis (Fig. 1A) and among 0.08 to $0.48 \mu \mathrm{W} / \mathrm{m}^{3}$ (Median: $0.19 \mu \mathrm{W} / \mathrm{m}^{3}$; Geometric mean: 0.19 $\mu \mathrm{W} / \mathrm{m}^{3}$ ) by in situ Gamma radiation spectrometry (Fig-1B). The mean of radioactive heat production of mylonite rocks from SPSPA $\left(0.22 \mu \mathrm{W} / \mathrm{m}^{3}\right)$ is significantly high concerning those predicted for ultrabasic rocks due to the geological alteration process. The respective average surface radioactive heat flow $\left(49.7 \mathrm{~mW} / \mathrm{m}^{2}\right)$ is to lower in relation to those predicted for the oceanic lithosphere (Fig. $1 \mathrm{C}, \mathrm{D}$ ), which indicates that the additional heat flow from the upper mantle is also low in the SPSPA area. Our date and another geological feature suggest that lithospheric mantle around the SPSPA area is colder than the upper mantle outside the Equatorial Atlantic area.

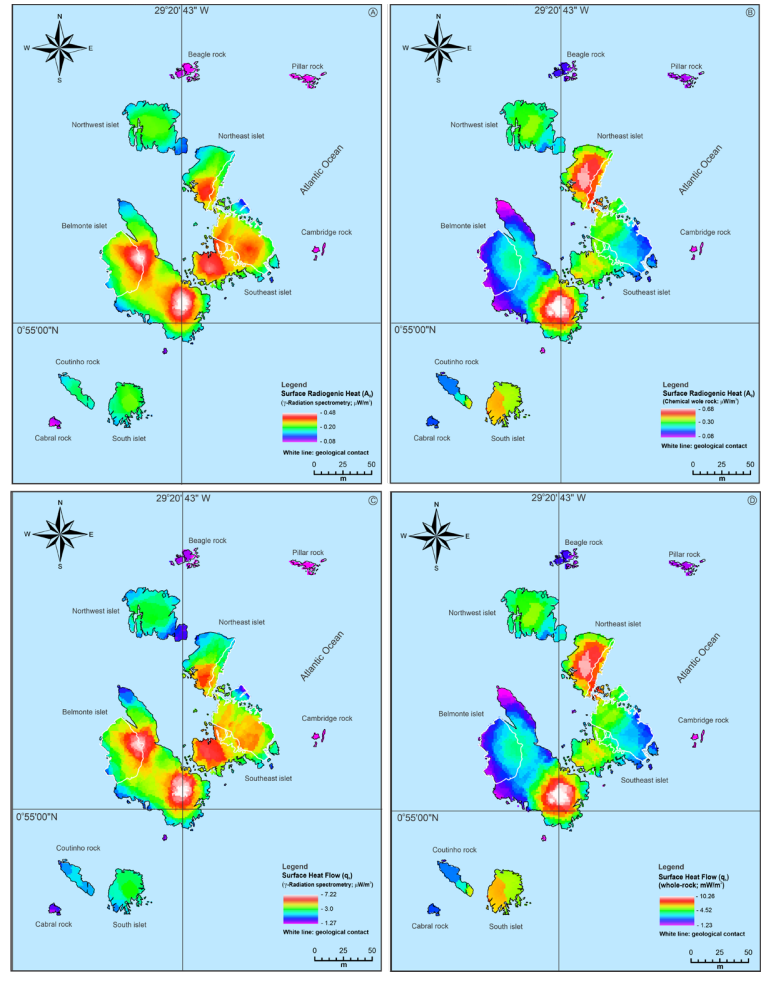

